Jurnal Ilmu Sosial dan Pendidikan (JISIP)

Vol. 6, No. 1 Januari 2022

e-ISSN : 2656-6753, p-ISSN: 2598-9944

DOI: 10.36312/ jisip.v6i1.2708/http://ejournal.mandalanursa.org/index.php/JISIP/index

\title{
Perlindungan Hukum Terkait Ekpresi Budaya Tradisional "Lagu Tradisional Aceh" Dalam Bingkai Hak Cipta
}

\author{
Tyas Adi Putra Nugraha \\ Magister Ilmu Hukum, Universitas Indonesia
}

\begin{tabular}{l}
\hline \hline Article Info \\
\hline Article history: \\
Received: 13 Desember 2021 \\
Publish: 02 Januari 2022
\end{tabular}

Keywords:

Traditional Cultural Expression

Aceh's Traditional Song, Inventory

\section{Info Artikel}

Article history:

Diterima: 13 Desember 2021

Publis: 02 Januari 2022

\begin{abstract}
Traditional Cultural Expression is an intellectual work that needs to be protected. Traditional Cultural Expression is rooted in three words: tradition, culture, and expression. The meaning of "expression", expresses a clear goal, idea or feeling. In this paper, the author raises an example of a traditional cultural expression, namely the cultural expression of traditional Acehnese songs owned by the local Acehnese people. Songs such as "Bungong Jempa", are a small example of the traditional wealth of the Acehnese people that should be preserved and protected by the government. The purpose of this study is to find out how is the protection related to traditional cultural expressions in Indonesia? And has the method of recording/inventorying traditional cultural expressions in Indonesia provided maximum protection for the cultural expressions of traditional Acehnese songs? The benefit of this research is that it is hoped that it can provide benefits for the development of legal knowledge in Indonesia and can provide insight or information to the public, especially regarding the object of copyright as one of the productive waqf in Indonesia.

Keywords:

\section{ABSTRAK}

Ekspresi Budaya Tradisional merupakan suatu karya intelektual yang perlu mendapatkan perlindungan. Ekspresi Budaya Tradisional berakar dalam tiga kata: tradisi, budaya, dan ekspresi. Makna "ekspresi", mengungkapkan menegenai tujuan yang jelas, ide atau perasaan. Pada tulisan ini penulis mengangkat contoh dari ekspresi budaya tradisonal yaitu ekspresi budaya lagu tradisional Aceh yang dimiliki masyarakat local Aceh. Lagu seperti "Bungong Jempa", menjadi contoh kecil dari kekayaan tradisional masyarakat Aceh yang semestinya dilestarikan dan mendapat perlindungan dari pemerintah. Tujuan penelitian ini adalah untuk mengetahui Bagaimanakah perlindungan terkait ekspresi budaya tradisional di Indonesia? Dan Apakah metode pencatatan/inventarisasi terhadap ekspresi budaya tradisional di Indonesia sudah memberikan perlindungan maksimal atas ekspresi budaya lagu tradisional Aceh? Manfaat dari penelitian ini yaitu diharapkannya dapat memberikan manfaat bagi perkembangan khazanah ilmu hukum di Indonesia dan dapat memberikan wawasan atau informasi kepada masyarakat khususnya mengenai objek hak cipta sebagai salah satu wakaf produktif di Indonesia.
\end{abstract}

This is an open access article under the Lisensi Creative Commons Atribusi-BerbagiSerupa

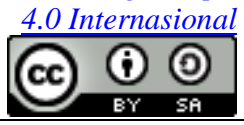

\section{Corresponding Author:}

Tyas Adi Putra Nugraha

Magister Ilmu Hukum, Universitas Indonesia

E-mail: adiputratyas@gmail.com 


\section{PENDAHULUAN \\ Latar Belakang}

Ekspresi Budaya Tradisional (EBT) merupakan suatu karya intelektual yang perlu mendapatkan perlindungan. Ekspresi Budaya Tradisional (EBT) berakar dalam tiga kata: tradisi, budaya, dan ekspresi. Makna "ekspresi", mengungkapkan menegenai tujuan yang jelas, ide atau perasaan. Budaya. Kata Budaya berasal dari bahasa Sansekerta, "budhayah" yang berarti pikiran atau intelektual. Ketika kita berbicara ekspresi budaya tradisional, maka ini merupakan suatu ciri dari masyarakat adat karena memuat tentang karakteristik berupa karya ekspresi dari suatu budaya yang mengandung identitas warisan budaya serta nilai-nilai kearifan local sehingga menjadi cerminan atas pengetahuan dan keterampilan yang kemudian di-transformasikan dari nilai-nilai mendasar dan keyakinan.

Secara umum, budaya dapat didefinisikan sebagai sesuatu yang dihasilkan oleh pikiran manusia dan intelek untuk mengembangkan dan mempertahankan hidup mereka di lingkungan mereka. Dengan demikian EBT adalah bagian dari kehidupan budaya masyarakat sebagai pemilik. Di dalam EBT mengandung beberapa nilai seperti ekonomi, spiritualitas, dan komunalitas Nilainilai EBT dihormati oleh masyarakat tradisional. Oleh karena itu, EBT selayaknya dapat mewakili identitas masyarakat adat di daerah tertentu. Budaya tradisional adalah suatu identitas dari bangsa Indonesia yang dapat dimanfaatkan secara ekonomi demi kemajuan dan kesejahteraan masyarakat yang wajib dilindungi.

Sebagai salah satu bentuk karya intelektual yang berasal dari budaya tradisional yaitu ekspresi budaya tradisional atau expression of folklore. Budaya tradisional merupakan bagian kehidupan suatu masyarakat pemilik budaya tersebut yang mengandung nilai ekonomi, nilai-nilai adat (termasuk spiritual), maupun nilai komunal yang menjadi bagian penting baik dari masyarakat tradisional tersebut. Folklore merupakan kebudayaan yang kolektif yang tersebar dan diwariskan secara tradisional dalam versi yang berbeda, baik dalam bentuk lisan maupun contoh yang disertai dengan gerak isyarat atau alat pembantu pengingat. Dalam menetapkan ciptaan sebagai folklore, permasalahan mengenai kejelasan lembaga pelaksana tetap saja ada. Hal tersebut terjadi, karena lembaga yang disebut dalam instrument perlindungan ekspresi budaya tradisional hanyalah Negara.

Sebagai negara yang memiliki budaya tradisional yang melimpah, maka sejatinya Indonesia memiliki potensi baik potensi ekonomi maupun potensi pariwisata. Budaya tradisional sejatinya perlu mendapatkan perlindungan karena sebagai identitas diri Indonesia yang dapat dimanfaatkan secara ekonomi demi kesejahteraan rakyat Indonesia. Komitmen Pemerintah, Pemerintah Daerah, maupun masyarakat diperlukan dalam mengupayakan perlindungan terhadap ekspresi budaya tradisional Indonesia. Perlindungan yang maksimal terhadap ekspresi budaya tradisional membutuhkan kerjasama yang baik antara Pemerintah dengan Pemerintah Daerah. Pemerintah Daerah baik pada tingkat provinsi atau kabupaten/kota perlu merumuskan suatu kebijakan daerah terkait perlindungan terhadap budaya tradisional. Instrumen hukum nasional maupun internasional telah mengatur mengenai perlindungan atas ekspresi budaya tradisional. Ditinjau dari perspektif hak kekayan intelektual, pengaturan terkait hak kekayaan intelektual di Indonesia yaitu pengaturan mengenai hak cipta. Undang-Undang Hak Cipta memberikan perlindungan kekayaan intelektual bagi seni dan budaya tradisional Indonesia. Dalam pasal 38 Undang-Undang Hak Cipta Nomor 28 Tahun 2014 menyebutkan bahwa disebutkan bahwa:

a. Hak cipta atas ekspresi budaya tradisional dipegang oleh negara.

b. Negara wajib menginvetarisasikan, menjaga, dan memelihara ekspresi budaya tradisional sebagaimana dimaksud pada ayat (1)

c. Penggunaan ekspresi budaya tradisional sebagaimana dimaksud pada ayat (1) harus memperhatikan nilai-nilai yang hidup dalam masyarakat pengembannya.

d. Ketentuan lebih lanjut mengenai hak cipta yang dipegang oleh negara atas ekspresi budaya tradisional sebagaimana dimaksud pada ayat (1) diatur dengan Peraturan Pemerintah. 
Pembahasan perlindungan hukum Ekspresi Budaya Tradisional sangat terkait dengan tiga unsur penting yaitu:

a. Adanya penyalahgunaan ekspresi budaya tradisional oleh pihak asing yang diantaranya menggunakan sistem Hak Kekayaan Intelektual;

b. Terkaitnya negara untuk menerapkan sistem perlindungan Hak Kekayaan Intelektual;

c. Buruknya sistem perlindungan ekspresi budaya tradisional.

Persoalan yang kerap muncul dari ekspresi budaya tradisional ini yaitu terkait isu kepemilikan dan perlindungan dari Ekspresi Budaya Tradisional dinilai lebih urgen daripada isu ekonomi atau komersialisasi Ekspresi Budaya Tradisional tersebut. Hasil penelitian Peter Jaszi menunjukkan bahwa yang menjadi keprihatinan di Indonesia, khususnya di kalangan seniman tradisional dan ketua kelompok masyarakat adalah masalah pernyataan dan pengakuan bahwa mereka adalah kustodian dan penjaga dari Ekspresi Budaya Tradisional di Indonesia, bukan masalah ekonomi dan komersialisasi dari Ekspresi Budaya Tradisional itu sendiri.

Selanjutnya, bagaimana Undang-Undang Hak Cipta dapat memberikan instrument perlindungan atas suatu ekspresi budaya tradisional. Bentuk-bentuk perlindungan tersebut ternyata mendapat persoalan juga terkait regulasi. seperti dalam kasus perlindungan atas ekspresi budaya dalam perspektif UUHC, tujuan filosofi dari hak cipta yang individual-ekslusif sehingga selalu diketahui penciptanya untuk kemudian mendapatkan perlindungan guna memperoleh manfaat ekonomi bertentangan dengan Ekspresi Budaya Tradisional yang lebih bersifat komunal dan tujuan lahirnya untuk kepentingan keagamaan atau adat istiadat yang bersifat sacral. Pada tulisan ini penulis mengangkat contoh dari ekspresi budaya tradisonal yaitu ekspresi budaya lagu tradisional Aceh yang dimiliki masyarakat local Aceh. Lagu seperti "Bungong Jempa", menjadi contoh kecil dari kekayaan tradisional masyarakat Aceh yang semestinya dilestarikan dan mendapat perlindungan dari pemerintah.

\section{Rumusan Masalah}

a. Bagaimanakah perlindungan terkait ekspresi budaya tradisional di Indonesia?

b. Apakah metode pencatatan/inventarisasi terhadap ekspresi budaya tradisional di Indonesia sudah memberikan perlindungan maksimal atas ekspresi budaya lagu tradisional Aceh?

\section{METODE PENELITIAN}

Dalam penelitian ini, penulis menggunakan jenis penelitian hukum yuridis normatif, yakni penelitian yang difokuskan untuk mengkaji teori dalam hukum positif dan diharapkan menghasilkan jawaban dalam penelitian yang penulis tulis ini. Penelitian normatif yang dimaksud yaitu bahwa permasalahan hukum yag dikaji / menjadi objek analisis yaitu terkait Lagu tradisional Aceh sebagai ekspresi budaya tradisional. Dalam upaya memecahkan permasalahan dalam penelitian ini, maka penulis menggunakan penelitian hukum melalui pendekatan. Multi-disiplin yaitu menggunakan landasan teoritis dan metodologi hukum yang ditemtukan secara cermat yang dipandang relevan, dengan memanfaatkan hasil kajian disiplin-disiplin non-hukum seperti sosiologi sebagai alat pengolah data tambahan guna memperoleh pemahaman lebih besar dan mendalam tentang eksistensi hukum sebagai azas dan norma di dalam sistem hukum. Yang kedua peneliti menggunakan Pendekatan Perundang-undangan (statute approach) yaitu pendekatan dengan menelaah dan menganalisis peraturan perundang-undangan dengan peraturan perundang-undangan yang berlaku. Teknik analisis bahan hukum pada penulisan ini menggunakan metode deduksi. Penggunaan metode deduksi berpangkal dari pengajuan premis mayor (yang versifat umum), kenudian diajukan premis minor (yang bersifat khusus), dari kedua premis tersebut kemudian ditarik kesimpulan atau conclusion. Dalam penelitian ini penulis menggunakan teknik analisis data dengan logika deduktif, logika desduktif atau pengolahan bahan hukum dengan cara deduktif yang menjelaskan suatu hal yang bersifat umum kemudian menariknya ke kesimpulan yang lebih khusus. 
Selanjutnya memadukan wawancara yang sudah dilakukan dengan peraturan perundang-undangan yang terkait dengan isu yang penulis tulis.

\section{HASIL DAN PEMBAHASAN}

\section{a. Pengaturan Terkait Perlindungan Ekspresi Budaya Tradisional di Indonesia}

Sebagai negara kepulauan, Indonesia memiliki kenaekaragaman seni dan budaya tradisional yang diciptakan oleh masyarakat adat. Sebagai tanda identitas sosial dan budaya berdasarkan standar dan nilai, pertumbuhan dan perkembangan dalam masyarakat memerlukan perlindungan hukum. negara, khususnya masyarakat Indonesia. Masyarakat adat sebagai simbol identitas nasional, di mana terdapat hak-hak masyarakat adat, diantaranya perlu mendapatkan perlindungan hukum sebagai bentuk penghormatan dan penghargaan terhadap hak-hak masyarakat adat atas karyanya. Perlindungan hak atas kekayaan budaya tradisional merupakan salah satu kewajiban pemerintah, salah satunya kewajiban konstitusional nasional berdasarkan Undang-Undang Dasar Negara Republik Indonesia Tahun 1945. Masyarakat adat merupakan bagian dari kebudayaan nasional Negara Kesatuan Republik Indonesia dalam perkembangannya. Negara melindungi hak-hak masyarakat dalam pengembangan nilai-nilai budayanya, sebagaimana dijelaskan dalam Pasal 18(B(2), Pasal 28(3)), dan Pasal 32(1) Undang-Undang Dasar Negara Republik Indonesia Tahun 1945. Selain hukum nasional terdapat juga beberapa instrument hukum internasional yang mengatur terkait perlindungan ekspresi budaya tradisional, yaitu terdapat di beberapa konvensi internasional antara lain, Berne Convention, The Model of Provision 1982, dan Refised Draft Provisions for The Protection of Traditional Cultural Expression/Expression of Folklore.

Hak Kekayaan Intelektual adalah hak atas kekayaan yang berasal dari karya intelektual manusia, yaitu hak yang berasal dari kreatifitas daya pikir manusia yang diekspresikan dalam berbagai bentuk karya yang bermanfaat serta berguna untuk menunjang kehidupan. Melalui perspektif ini, instrumen hukum yang melindungi EBT berada dibawah naungan rezim hak cipta. Pemerintah Indonesia juga telah mengambil kebijakan dalam melindungi ekspresi budaya tradisional sebagaimana diatur dalam Pasal 38 UU Hak Cipta Tahun 2014, yang berisi:

1) Hak Cipta atas ekspresi budaya tradisional dipegang oleh Negara.

2) Negara wajib menginventarisasi, menjaga, dan memelihara ekspresi budaya tradisional sebagaimana dimaksud pada ayat (1).

3) Penggunaan ekspresi budaya tradisional sebagaimana dimaksud pada ayat (1) harus memperhatikan nilai-nilai yang hidup dalam masyarakat pengembannya.

4) Ketentuan lebih lanjut mengenai Hak Cipta yang dipegang oleh Negara atas ekspresi budaya tradisional sebagaimana dimaksud pada ayat (1) diatur dengan Peraturan Pemerintah.

Maka dapat terlihat dengan dimasukkannya Ekspresi Budaya Tradisional dalam UU No. 28 Tahun 2014 Tentang Hak Cipta, karena hak cipta merupakan salah satu cabang dari hak kekayaan intelektual yang memasukkan EBT kedalam ranah seni, sastra, dan ilmu pengetahuan. Meskipun hak cipta dapat melindungi ekspresi budaya tradisional. Namun masa perlindungan hak cipta tidak dapat diterapkan pada ekspresi budaya tradisional, karena ekspresi budaya tradisional tidak hanya mengejar nilai komersial (hak ekonomi), tetapi juga alasan budaya dan spiritual yang ada di masyarakat, menggunakan dan mengizinkan suatu ciptaan menjadi milik umum (public domain) setelah jangka waktu tertentu bertentangan dengan tujuan penciptaan itu sendiri. Hal ini sejalan dengan Pasal 60 UUHC, yaitu perlindungan hak cipta ekspresi budaya tradisional milik bersama berlaku tanpa batas waktu. Pasal ini jelas bertujuan untuk melindungi karya-karya tradisional.

Perlindungan yang dimaksud adalah segala bentuk upaya melindungi ekspresi budaya tradisional terhadap pemanfaatan yang dilakukan tanpa hak dan melanggar kepatutan. 
Perlindungan ekspresi budaya tradisional sebagai bagian pengetahuan tradisional ini sangat penting, setidaknya karena 3 alasan, yaitu (1) adanya potensi keuntungan ekonomis yang dihasilkan dari pemanfaatan pengetahuan tradisional, (2) keadilan dalam sistem perdagangan dunia, dan (3) perlunya perlindungan hak masyarakat local.

Oleh karena itu, dalam hal ini negara berkewajiban untuk mensosialisasikan konsep hak cipta melalui pemerintah daerah, dan mendaftarkan hak cipta dengan cara mencatat, mendaftarkan dan menyusun seluruh ekspresi budaya tradisional masyarakat hukum adat Toraki yang memiliki potensi ekonomi. Sebagai pemilik hak cipta ekspresi budaya tradisional, negara memperoleh hak eksklusif atas karya cipta. Hak eksklusif menurut Undang-Undang Hak Cipta adalah hak untuk menerbitkan, memperbanyak, menerjemahkan, mengadaptasi, mengatur, mengubah, mendistribusikan, menampilkan, menerbitkan, menyebarluaskan, dan menyewakan karya ciptaan. Maka, dapat dikatakan bahwa perlindungan Ekspresi Budaya Tradisional dapat meningkatkan kesejahteraan, tidak hanya bagi para penciptanya saja, namun bagi bangsa dan negara Indonesia. Hal penting lainnya juga untuk menjaga identitas budaya Aceh yang merupakan kekayaan nasional, dari ancaman pengakuan kepemilikan negara lain atau pemanfaatan oleh warga negara asing.

Perlindungan Ekspresi Budaya Tradisional dapat dilakukan dengan metode basis data sebagai bentuk atas publikasi dan perlindungan hak cipta terhadap ekspresi budaya tradisional sebagai bukti kepemilikan. Yang dimana, perlindungan dan pemanfaatan dari ekspresi budaya ini merupakan suatu upaya pemajuan kebudayaan. Terdapat empat aspek yang mempengaruhi demi terciptanya suatu pemajuan kebudayaan, yaitu;

1) Perlindungan, yaitu suatu upaya demi menjaga suatu keberlanjutan kebudayaan yang dilakukan dengan inventarisasi, pemeliharaan, dan publikasi

2) Pengembangan, yaitu upaya demi menghidupkan suatu kebudayaan dengan cara meningkatkan, memperluas, dan memyebarluaskan kebudayaan.

3) Pemanfaatan, merupakan suatu upaya pendayagunaan objek dari pemajuan kebudayaan demi menguatkan ideologi, politik, ekonomi, sosial, budaya, pertahanan, dan keamanan dalam mewujudkan tujuan nasional

4) Pembinaan, adalah upaya pemberdayaan Sumber Daya Manusia atas kebudayaan, Lembaga kebudayaan demi memperluas peran dan inisiatif masyarakat.

\section{b. Pelaksanaan Inventarisasi Atas Ekspresi Budaya Tradisional}

Terkait perlindungan atas ekspresi budaya tradisional, langkah yang harus diambil agar mendapatkan perlindungan maksimal yaitu inventarisasi. Inventarisasi atas ekspresi budaya tradisional terdiri dari beebrapa tahapan, yakni pencatatatn dan pendokumentasian, penetapan, dan pemutakhiran data dengan melalui system kebidayaan terpadu. Perlindungan terhadap pengetahuan tradisional dilakukan dengan cara terus memperbaharui data, mewariskan pengetahuan tradisional kepada generasi berikutnya, dan mengupayakan pengetahuan tradisional sebagai warisan budaya dunia. Melaksanakan perlindungan atas pengetahuan untuk mencegah pihak asing mengklaim pengetahuan tradisional. Namun, bentuk-bentuk perlindungan pengetahuan tradisional lainnya tidak diatur dalam Undang-Undang Pemajuan Kebudayaan.

Seperti contoh dari beberapa pengetahuan tradisional ini bersifat sakral dan rahasia, sehingga perlu untuk mencegah penyalahgunaan (misappropriation) atau penggunaan yang tidak semestinya oleh pihak manapun Orang Asing atau Warga Negara Indonesia sendiri. Perkembangan dan percepatan teknologi dapat menyebabkan penyalahgunaan atau eksploitasi Tidak layak untuk pengetahuan tradisional. Pengetahuan tradisional dikomersialkan tanpa menghormati kepentingan budaya, masyarakat adat sebagai pemilik. Selain itu, bentuk perlindungan terhadap pengetahuan tradisional adalah pemeliharaan untuk mencegah kerusakan, kehilangan atau kehancuran pengetahuan tradisional. Pemeliharaan pengetahuan 
tradisional adalah dengan menjaga keluhuran dan kearifan pengetahuan tradisional menggunakan pengetahuan tradisional dalam kehidupan sehari-hari, menjaga keragaman pengetahuan tradisional, menghidupkan kembali dan menjaga ekosistem budaya masing-masing pengetahuan tradisional, dan mewariskan pengetahuan tradisional kepada generasi selanjutnya.

Dengan banyaknya jumlah dari ekspresi budaya tradisional yang ada di Indonesia, inventarisasi dianggap menjadi factor penting dalam perlindungan budaya tradisional. Inventarisasi merupakan bentuk dari defensive protection. Langkah negara dalam memanfaatkan defensive protection adalah demi membangun database yang berkaitan dengan karya-karya yang dilindungi dalam Undang-Undang Hak Cipta. Berdasarkan Peraturan Menteri Dalam Negeri dan Menteri Kebudayaan dan Pariwisata Nomor 42 dan Nomor 40 Tahun 2009 Tentang Pedoman Pelestarian Kebudayaan pada pasal 2 ayat (1) juga dijelaskan mengenai tanggung jawab pemerintah daerah melaksanakan pelestarian kebudayaan di daerah, dalam hal ini yang dimaksud sebagai pemerintah daerah dibagi menjadi dua yakni: pemerintah provinsi dan pemerintah kabupaten/kota.

Apabila kita kaitkan dengan status ekspresi budaya lagu tradisional Aceh, dalam pelaksanaan kewajiban inventarisasi masi terlihat belum terlaksana dengan baik. Dalam perlindungannya, terdapat juga penghambat dalam perlindugan suatu ekspresi budaya tradisional Aceh yaitu karena kurangnya budaya atau etika bangsa Indonesia dalam hal ini masyarakat sekitar terhadap rasa menghargai ciptaan seseorang dan kurang pemahaman masyarakat dan penegakkan hukum tentang arti dan fungsi hak cipta serta kurangnya fungsi pencegahan dari Undang-Undang Hak Cipta. Selanjutnya, Soerjono Soekanto juga menjelaskan bahwa terdapat lima factor, yaitu faktor hukum, penegak hukum, factor sarana dan prasarana, factor masyarakat, dan yang terakhir, factor kebudayaan. Kelima faktor tersebut berkaitan erat karena merupakan esensi dari penegakan hukum, yang sangat berkaitan dengan perlindungan hukum itu sendiri. Ini juga menjadi tolak ukur penegakan hukum.

Maka, ekspresi budaya tradsional ini tidak hanya mengutamakan kepentingan masyarakat daerah sebagai pemiliknya, tetapi juga mengutamakan fungsi social dari masyarakat Indonesia. Sehingga ekspresi budaya tradisional ini bisa menjadi suatu kekayaan budaya milik masyarakat Indonesia.

\section{KESIMPULAN}

a. Hak Kekayaan Intelektual adalah hak atas kekayaan yang berasal dari karya intelektual manusia, yaitu hak yang berasal dari kreatifitas daya pikir manusia yang diekspresikan dalam berbagai bentuk karya yang bermanfaat serta berguna untuk menunjang kehidupan. Melalui perspektif ini, instrumen hukum yang melindungi EBT berada dibawah naungan rezim hak cipta. Pemerintah Indonesia juga telah mengambil kebijakan dalam melindungi ekspresi budaya tradisional sebagaimana diatur dalam Pasal 38 UU Hak Cipta Tahun 2014. Perlindungan Ekspresi Budaya Tradisional dapat dilakukan dengan metode basis data sebagai bentuk atas publikasi dan perlindungan hak cipta terhadap ekspresi budaya tradisional sebagai bukti kepemilikan. Yang dimana, perlindungan dan pemanfaatan dari ekspresi budaya ini merupakan suatu upaya pemajuan kebudayaan

b. Inventarisasi atas ekspresi budaya tradisional terdiri dari beebrapa tahapan, yakni pencatatatn dan pendokumentasian, penetapan, dan pemutakhiran data dengan melalui system kebidayaan terpadu. Perlindungan terhadap pengetahuan tradisional dilakukan dengan cara terus memperbaharui data, mewariskan pengetahuan tradisional kepada generasi berikutnya, dan mengupayakan pengetahuan tradisional sebagai warisan budaya dunia. Melaksanakan perlindungan atas pengetahuan untuk mencegah pihak asing mengklaim pengetahuan tradisional. Namun, bentuk-bentuk perlindungan pengetahuan tradisional lainnya tidak diatur dalam Undang-Undang Pemajuan Kebudayaan. Pemeliharaan pengetahuan tradisional adalah 
dengan menjaga keluhuran dan kearifan pengetahuan tradisional menggunakan pengetahuan tradisional dalam kehidupan sehari-hari, menjaga keragaman pengetahuan tradisional, menghidupkan kembali dan menjaga ekosistem budaya masing-masing pengetahuan tradisional, dan mewariskan pengetahuan tradisional kepada generasi selanjutnya.

\section{DAFTAR PUSTAKA}

Adami Chazawi, 2007, Tindak Pidana Hak atas Kekayaan Intelektual (HAKI), Bayumedia Publishing, Malang.

Agus Sardjono, 2006, Hak Kekayaan Intelektual dan Pengetahuan Tradisional, Alumni,Bandung, Undang-Undang Pemajuan Kebudayaan

Arfirillyanna Purba, Pemberdayaan Perindungan Hukum Pengetahuan Tradisional dan Ekspresi Budaya Tradisional Sebagai Sarana Petumbuhan Ekonomi Indonesia, Alumni, Bandung: 2012.

Arif Lutviansori, 2010, Hak Cipta dan Perlindungan Folklor di Indonesia, Graha Ilmu, Yogyakarta.

Hendra Djaja, Perlindungan Hukum Terhadap Ekspresi Budaya Tradisional Dalam Perspektif Undang Undang Hak Cipta, Jurnal Cakrawala Hukum, Fakultas Hukum Universitas Merdeka Malang, Vol. 7 No. 1 Juni 2016.

Ida Ayu Sukihana dan I Gede Agus Kurniawan, "Karya Cipta Ekspresi Budaya Tradisional: Studi Empiris Perlindungan Tari Tradisional Bali Di Kabupaten Bangli," Jurnal Magister Hukum Udayana (Udayana Master Law Journal) 7, no. 1: 2018.

James Danandjaja, Folklore Indonesia, Grafiti, Jakarta: 2002.

Jaszi, Peter, "Traditional Culture: A Step Forward for Protection in Indonesia", Washington College of Law Research Paper No. 2010-16, American University Washington College of Law, 2010.

Jonny Ibrahim, Teori \& Metodologi Penelitian Hukum Normatif, (Malang: Banyumendia,2007)

Simona Bustani, "Urgensi Pengaturan Ekspresi Budaya (Folklore) Masyarakat Adat," Jurnal Hukum Prioris 2, no. 4: 2010

Sukihana, I., \& Kurniawan, I. 2018. Karya Cipta Ekspresi Budaya Tradisional: Studi Empiris Perlindungan Tari Tradisional Bali di Kabupaten Bangli. Jurnal Magister Hukum Udayana Udayana Master Law Journal).

Undang-Undang Nomor 28 Tahun 2014 Tentang Hak Cipta

WIPO Publication, Consolidated Analysis of The Legal Protection of Traditional Cultural Expression/Expression of Folklore, May 2003 